\title{
DOCUMENTATION
}

\section{AN OPEN LETTER: A CALL TO PEACE, DIALOGUE AND UNDERSTANDING BETWEEN MUSLIMS AND JEWS ${ }^{1}$}

\author{
Bismillah Ar Rahman Ar Rahim*
}

In the name of God the Beneficent, the Merciful

Surely those who believe, and those who are Jews, and the Christians, and the Sabians, whoever believes in God and the Last day and does good, they shall have their reward from their Lord, and there is no fear for them, nor shall they grieve. (Qur'an 2:62)

Shalom,

Assalam alaykum,

This letter is intended as a gesture of goodwill towards rabbinic leaders and the wider Jewish communities of the world. Our aim is to build upon existing relations in order to improve mutual understanding in places where this is required to further the positive work in building bridges between Muslims and Jews. In the face of the negative and destructive tensions in the Middle East, this letter is a call to positive and constructive action that aims to improve Muslim-Jewish relations.

Many Jews and Muslims today stand apart from each other due to feelings of anger, which in some parts of the world, translates into violence. It is our contention that we are faced today not with 'a clash of civilizations' but with 'a clash of ill-informed misunderstandings'. Deep-seated stereotypes and prejudices have resulted in a distancing of the communities and even a dehumanizing of the 'Other'. We urgently need to address this situation. We must strive towards turning ignorance into knowledge, intolerance into understanding, and pain into courage and sensitivity for the 'Other'.

For many centuries our communities coexisted and worked together fruitfully and peacefully, such as in the Iberian Peninsula. As Muslims and Jews we share core doctrinal beliefs, the most important of which is strict monotheism. We both share a common patriarch, Ibrahim/Abraham, other

* This letter had 40 Muslim signatories. A full list can be found at: www.woolfinsititute.cam.ac.uk/cmjr/lettersignup.php 
Biblical prophets, laws and jurisprudence, many significant values and even dietary restrictions. There is more in common between our religions and peoples than is known to each of us. It is precisely due to the urgent need to address such political problems as well as acknowledge our shared values that the establishment of an inter-religious dialogue between Jews and Muslims in our time is extremely important. Failure to do so will be a missed opportunity. Memories of positive historical encounters will dim and the current problems will lead to an increasing rift and more common misunderstandings between us.

This letter is important for non-Muslims and Muslims alike because it illustrates that the Muslim world has diversity of opinion and that Muslims are willing to engage in a conversation with Jews - a conversation that is not wholly dominated by the conflict in Israel-Palestine. Although many Muslims and non-Muslims only know of Muslim-Jewish relations through the prism of the Israeli-Palestinian conflict, there needs to be an awareness of other positive encounters at different stages of our history as well as the pioneering work of inter-religious dialogue being undertaken by contemporary Muslims and Jews outside of the Middle East.

\section{What are the Commonalities and Differences between Us?}

Judaism and Islam are both monotheistic religions whose followers believe in the absolute unity of the One and Only God, as emphasized by Muslims in the Shahada, Qur'an 112:1-4, and by Jews in the Shema, Deuteronomy 6:4; as well as Ibrahim/Abraham, they share other common patriarchs such as Nuh/Noah; and Jews and Muslims, as well as Christians, are regarded by Muslims as 'People of the Book'. All Muslims, regardless of their theological persuasion (Sunnis and Shi'as) believe, as an article of their faith, in all Biblical Prophets.

Say [O Muslims!]: 'We believe in God', in that which has been revealed to us; in that which was revealed to Abraham, Ishmael, Isaac, Jacob, and their descendents; in that which was given to Moses and Jesus; and in that which was given to the Prophets from their Lord; we do not make any distinction between any of them, and to Him we are Muslimun (those who submit to his will). (Qur'an 2:136)

As a pillar of our faith (Iman), we (Muslims) are expected to believe that the author of the Torah (Tawrat) and the Qur'an is the same one God:

It was We (God) who revealed the Torah (to Moses): therein was guidance and light. By its standard have been judged the Jews, by the prophets who bowed to God's will, by the Rabbis and the doctors of law: for to them was entrusted the protection of God's book, and they were witnesses thereto. (Qur'an 5:44) 
Thus, for us as Muslims the message of the Prophet Muhammad is an extension and continuation of the message brought from God by Moses, and other Prophets:

The Messenger (Muhammad) believes in that which has been revealed to him from his Lord, and so do the believers; they all believe in God, His angels, His Books, and His Messengers; [they say] we make no distinction between any of His Messengers; and they say: 'We hear and obey (God's commandments); grant us your forgiveness, our Lord. And to you is the eventual course'. (Qur'an 2:285)

Jews and Muslims both have elaborate and comparable codes of conduct, laws and jurisprudence, covering all aspects of life (the Sharia in Islam and the Halacha in Judaism). The importance of charity (sadaka, tsedaka) is pertinent to the value system of each tradition. Even the dietary procedures (halal and kashrut/kosher) are comparable. Jews and Muslims have contributed to a highly sophisticated form of art and architecture. Indeed, Islamic art has influenced the architecture of many synagogues and, in parts of the Muslim world where coexistence was once prevalent, Jewish symbols still decorate Islamic buildings.

Prejudice and bigotry towards each other have been perpetuated by our lack of knowledge about the other and yet the pursuit of knowledge is at the core of both our religious traditions. Indeed, the fact that the term 'Torah' means 'teaching' and 'Qur'an' means 'reading' should instil in us the desire to read, understand and teach about each other.

Yes, there are texts in both our religious traditions which, when interpreted literally outside of their specific contexts can damage relations and stifle attempts to engage in solidarity and inter-religious dialogue. For the majority of Muslims, such texts reflect the political discourse and shifts in relations between Muslims and the religious 'Other' in seventh-century Arabia. The Qur'an constantly reminds Muslims that 'among' the People of the Book are those who believe and do righteous deeds.

Among the People of the Book there is a staunch and just community who recite the revelations of God in the night season, falling prostrate (before Him). They believe in God and the Last Day; they enjoin what is right, and forbid what is wrong; and they hasten (in emulation) in (all) good works: They are in the ranks of the righteous. And whatever good they do, they will not be denied the reward thereof. For God knows well those that do right. (Qur'an 3:113-115; see also 3:199)

The word 'among' is an important modifier that has been forgotten and is often overlooked by many readers of the Qur'an today, whether Muslim or non-Muslim. Yet, in today's world, it is easy to label Jews, Muslims or Christians with one sweeping brush stroke; but a careful and thoughtful 
reading of the Qur'an or Torah reveals a far more sophisticated approach of seeing, acknowledging and appreciating the diversity of the human family.

O mankind, truly We have created you male and female, and have made you nations and tribes that ye may recognize one another (Qur'an 49:13).

This, to us as Muslims and Jews, enforces the will of our Creator who urges us to read, understand and teach - can there be a more noble way in which to uphold this core message of the Creator than to learn more about each other? In this way, we will replace prejudice, ignorance and intolerance by knowing, understanding and being sensitive to the 'Other', who becomes our 'brother' and 'sister'.

\section{Jews and Muslims as One Umma: Reflecting Briefly on Early Muslim-Jewish Encounters}

In the spirit of Islam's emphasis on compassion and respect for all humanity, one vignette from the Prophet's life reveals how a Jewish funeral procession passed before the Prophet Muhammad (peace be upon Him), at which he stood up as a sign of respect. His companions asked him, why he stood up for a Jewish funeral? The Prophet dismissed this exclusivist attitude and rising above these polarities responded on a humanitarian level, 'is he not a human being!' (as recorded in Sahih al-Bukhari, a collection of statements and traditions by and about the Prophet Muhammad in the Book on Funeral Procession, Section on 'Standing up in respect of a Jewish Funeral').

In the year $622 \mathrm{CE}$, when the Prophet was exiled from Mecca, his city of birth, he migrated to Yathrib (Medina). Upon his arrival in the city, the Prophet declared in the now famous Medina Charter that the Jewish tribes of Medina constituted the new one umma (nation) together with the Muslims.

This is a document from Muhammad the Prophet, governing relations between the Believers i.e. Muslims of Quraysh and Yathrib and those who followed them and worked hard with them. They form one nation ummah.

No Jew will be wronged for being a Jew.

The enemies of the Jews who follow us will not be helped.

Those Jews who live peacefully with the Believers will be helped and will be treated with equality.

The Jews of the tribe of Bani Awf will be treated as one ummah with the Believers.

Thus, the document refers to the Jews and Muslims as ummatun wahidatun ('one nation'), a term that recurs in the Qur'an a number of times to denote a 
people united by common values and beliefs. Therefore, Muslim-Jewish encounters have had their moment of friendship as well as tension.

When the Prophet died his shield was mortgaged with a Jew to show that Muslims are permitted to trade with Jews. More significantly, the Prophet's married daughter Hazrat Fatima, who was very close to her father, used to work for a Jew - she would spin for him in return for grain. Moreover, the Prophet's wife, Sofia, was a Jewish woman who was considered by God as 'a mother of the believers'. When, out of human jealousy, the Prophet's other wives mocked Sofia by calling her 'a Jew' in a derogatory manner, Sofia who was clearly upset by their mocking would complain to her husband, the Prophet Muhammad. He would tell her to respond to them by saying: 'my father was a Prophet (Moses) and my uncle was a Prophet (Aron) and I am the wife of a Prophet!' Historically, Muslims and Jews have shared a common intellectual history: from the dissemination of the Isra'iliyyat (authenticated Jewish sources employed by early classical Muslim historians and commentators of the Qur'an), to the philosophical exchanges between Ibn Rushd (Averroes, 1126-1198) and Moses Maimonides (Musa ibn Maymun alQurtubi, 1135-1204) in Medieval Spain.

Sir Jonathan Sacks, the Chief Rabbi of the United Hebrew Congregations of the Commonwealth, on the inauguration of the world's first Centre for the Study of Muslim-Jewish Relations (in Cambridge), emphasized the importance of learning from each other. He said:

Islam's strength of faith is remarkable. We can all learn from Islam this strength of faith. And that is something immensely positive. If I wanted to suggest what Muslims can learn from Jews today, I would say how to survive as a minority in a culture that does not share your values. We have to learn from one another.

It was the intellectual world of Islam that brought to Europe in particular, and to the modern world in general, the lost tradition of the Greek Philosophers (for example, the works and ideas of Plato and Aristotle). Indeed, their teachings were first revived by Muslim scholars such as Al-Farabi, Ibn Sina, Ibn Rushd and others, who went on to influence the ideas and writings of many Jewish and Christian scholars, including Maimonides. In this intellectually thriving environment the passing of the flame of knowledge between religious scholars eventually influenced the development of secular humanism and contemporary sciences. In the example of Maimonides, who held the position of physician to the great Sultan Salah-ud-din, and Averroes, we observe a fruitful intellectual conversation and exchange between Islam, Judaism and Christianity. 


\section{Combating Estrangements and Negative Perceptions of the 'Other'}

European Jews and Muslims today share experiences as minority groups. With the increasing anti-Semitism and Islamophobia, Jews and Muslims need to develop joint strategies to tackle discrimination. They could also come together to support each other's efforts to maintain their identities in an age that promotes and expects conformity to the dominant culture. It is, therefore, in the spirit of both religious and geo-political compulsions that we emphasize the process of bridge-building between the two communities. This process must go beyond dialogue and move towards genuine understanding and encounters, such as visiting each other's places of worship.

It is important to be honest about the level of anti-Jewish and antiMuslim/anti-Arab sentiment that translates into conflict within and between the two communities. The need today is for us to see each other's history and appreciate each other's cultures with a genuine attempt at understanding.

At this moment, there is no challenge more pressing than the need to bring to a closure some of the historical and long-lasting estrangements between the Jews and Muslims. Because of the increasing polarisation, many feel forced to choose between dialogue and violence as a response. At the core of the Muslim-Jewish tension lies the Israeli-Palestinian conflict. The loss of every single life is a loss to humanity and a bloody stain on the tapestry of history. We call for a peaceful resolution that will assure mutual respect, prosperity and security to both Palestinians and Israelis, while allowing the Palestinian people their rights to self-determination.

Most Muslims would hope that the sufferings Jews have experienced over many centuries would make them more sensitive to the sufferings of others, especially the Palestinian people. In the Hebrew Bible Jews read how they are commanded to love the stranger because they themselves were strangers in the land of Egypt (this is mentioned thirty-six times in the Torah).

\section{A Call for Dialogue between People of All Faiths}

While the purpose of this letter is to generate dialogue and understanding between Jews and Muslims, it reflects the need for a wider dialogue between all faiths and communities, including the non-Abrahamic ones. We must keep talking - especially when we do not agree.

This is, therefore, an appeal and a hand held out, based on the teachings of both the Qur'an and the Hebrew Bible, in a genuine desire for dialogue and mutual respect: 
Turn from Evil and do good; seek peace and pursue it. (Tehilim/Psalms $34: 14)$

And the servants of the Infinitely Compassionate are those who walk on the earth in humility and when the ignorant accost them, they only reply with 'Peace!' (Qur'an 25:65)

May the peace and blessing of God Almighty be upon you, and may this letter be accepted as a small step towards opening doors to genuine dialogue and understanding. May it also lead the way towards concrete outcomes in Muslim-Jewish relations in different parts of our shared world.

\section{Note}

1. Muslim scholars from The Centre for the Study of Muslim-Jewish Relations, part of The Woolf Institute of Abrahamic Faiths, Cambridge, have facilitated this letter with the support of Muslims scholars throughout the world. For further information, see www.woolfinstitute.cam.ac.uk/cmjr. 